\title{
LA MISERICORDIA DE DIOS CON ROSTRO MATERNO ENCARNADO
}

DOI: https://doi.org/10.52039/seminarios.v62i216.143

ANA LAURA CASTILLO*

Como uno a quien su madre le consuela, así yo os consolaré (Is 66, 13).

Las imágenes de Dios son parte del lenguaje humano y se relacionan íntimamente con una cosmovisión y un contexto cultural particulares; las imágenes y símbolos son necesarios debido a nuestro estado corporal que exige estas representaciones definidas. Para los cristianos, Dios es un Dios personal y está cerca de su pueblo, no es una entidad especulativa, sino una realidad experiencial. Las imágenes que tenemos de Dios dependen de analogías, metáforas o antropomorfismos que tenemos de nuestra realidad humana.

La religión judeocristiana está representada por un Dios masculino: Dios es dios y no diosa, es Padre y no madre, tiene un Hijo y no una hija, sus servidores humanos son sacerdotes y no sacerdotisas, y esta idea parece de lo más natural. Para el pueblo de Israel (Antiguo Testamento), Yahvé es el único creador, es un Dios asexuado y sin familia.

Aunque en teología se dice que Dios es neutral, ni masculino ni femenino, que no hay género en Dios, generalmente se habla del Dios Padre, y en contadas ocasiones se mencionan las características maternas de Dios. Los tratados de teología y de espiritualidad destacan los rasgos paternos de Dios.

El predominio de las imágenes masculinas para hablar de Dios induce a pensar en él como un hombre, con las características de poder, autoridad y dominio patriarcales. El uso de un lenguaje exclusivamente androcéntrico para pensar y meditar sobre Dios ha limitado la realidad divina a lo masculino, y ha devaluado la comprensión de Dios como madre. Es un prejuicio la idea de que un hombre -varón- representa a Dios más significativamente, relegando a la mujer a un lugar secundario. «Un Dios descrito como varón se convierte en un

* Nacida en la ciudad de México, estudió la licenciatura de Relaciones Industriales en la Universidad Iberoamericana. Posteriormente, realizó estudios de filosofía y de teología en la Universidad Pontificia de México, especializándose en Teología Bíblica y Teología Espiritual, obteniendo el doctorado en ésta última. Ha publicado diversos trabajos sobre la mujer en la Biblia y en la Iglesia. 
varón Dios» ${ }^{1}$. Dios también puede ser como una madre tierna y misericordiosa, que coloca el amor a su hijo por encima de todo.

Hoy en día, es necesario tener una nueva visión y emplear un nuevo lenguaje (el lenguaje androcéntrico ha llevado a mantener un tipo de sociedad desigual, sacralizando las estructuras patriarcales) para hablar de Dios y reflexionar sobre su revelación, pues cuanto mayor sea la riqueza de nuestras experiencias y expresiones, mayor será nuestra comprensión de Dios. Así como Dios es padre igualmente es madre; hablar de un Dios-Padre-Madre tiene sentido porque las dos expresiones hablan de la totalidad esencial de Dios. Tanto lo femenino como lo masculino son capaces de simbolizar lo divino.

Encontramos diversas imágenes maternas de Dios precisamente en la Sagrada Escritura. En el AT se descubren citas que presentan a Yahvé con rasgos maternos, considerando la vida como un don gratuito del creador.

1. A continuación se presentan algunos textos que ejemplifican las funciones femeninas de Dios, que incluyen el amor, la misericordia, la fidelidad, el dolor y el sufrimiento de Dios por su pueblo, dando a la imagen materna de Dios un valor positivo: «Escuchadme, casa de Jacob, y todos los supervivientes de la casa de Israel, los que habéis sido transportados desde el seno, llevados desde el vientre materno. Hasta vuestra vejez, yo seré el mismo, hasta que se os vuelva el pelo blanco, yo os llevaré. Ya lo tengo hecho, yo me encargaré, yo me encargo de ello, yo os salvaré» (Is 46, 3-4).

Este texto se refiere al momento del exilio. Se presenta la metáfora del órgano físico de la mujer, el vientre: el pueblo de Israel había sido transportado, cargado en el vientre -órgano físico de la mujer (rejem)- de Dios. Rejem se relaciona con el verbo rajam, que significa amar, compadecerse, sentir cariño, tener piedad, misericordia. La mentalidad israelita considera que los sentimientos misericordiosos, como cargar en el vientre, alimentar y proteger, tienen su origen en las entrañas femeninas, lugar que representa a la madre como símbolo de ternura. Dios, como una madre humana, abarca toda la vida de su pueblo, desde el momento de la concepción hasta que su hijo, el pueblo, crezca y sea mayor. Se pasa del simbolismo del útero materno a la misericordia de Dios.

También en el profeta Isaías se pone en boca de Dios estas palabras: «Dice Sión: 'Yahvé me ha abandonado, el Señor me ha olvidado'. ¿Acaso olvida una mujer a su niño de pecho, sin compadecerse del hijo de sus entrañas? Pues aunque ésas llegasen a olvidar, yo no te olvido. Míralo, en las palmas de mis manos te tengo tatuada, tus muros están ante mí perpetuamente» (Is 49, 14-16).

Se perciben huellas del sufrimiento del exilio, pero ahora la respuesta de Yahvé refleja un acento maternal, un amor y misericordia divinos que son mayores que los de la mejor madre, un amor que sobrepasa cualquier amor humano.

1. I. Gómez-Acebo, Dios en la teología feminista: Estudios Eclesiásticos 78 (2003) 107-126. 
Yahvé expresa su fidelidad al pueblo, en una relación íntima, como la de la madre con su hijo, como el vínculo de amor entre la madre y su bebé.

Y en otro lugar: "Seréis alimentados, en brazos seréis llevados, sobre las rodillas seréis acariciados. Como aquel a quien su madre consuela, así yo os consolaré» (Is 66, 12-13).

Este texto refleja el amor y misericordia de Dios por su pueblo. El original hebreo no habla de brazo sino de cadera, que es el lugar habitual donde la mujer semita coloca al niño y donde, aún hoy, las madres nómadas del desierto llevan a sus bebés: colgados del cuello y apoyados en la cadera para tener las manos libres. El consuelo de la madre se amplía con la expresión «y sobre las rodillas seréis acariciados», pues la rodilla es el lugar primordial para sentar a los que se ama. Dios compara al pueblo con un niño querido que se acaricia.

2. Diversos símbolos que expresan lo femenino de Dios incluyen la función de Dios como partera: «Fuiste tú quien del vientre me sacó, a ti me confiaron al salir del seno, desde el vientre materno tú eres mi Dios» (Sal 22, 10-11); como el Dios que engendró a su pueblo: «jolvidas al Dios que te engendró!» (Dt 32, 18); como una mujer parturienta: «[Yahvé] estaba mudo desde mucho, me había reprimido. Como parturienta grito, resoplo y jadeo entrecortadamente» (Is 42, 14); como quien creó a Israel desde el seno: «Así dice Yahvé que te creó, te plasmó ya en el seno y te ayuda» (Is 44, 2).

3. La teóloga española Mercedes Navarro subraya el sentido de Dios como madre en el relato del éxodo de Israel. Dios es la madre del pueblo de Israel: Dios lo «concibe» como pueblo, y lo da a luz en cuanto que Dios proporciona a Israel una experiencia de nacimiento, como madre que da la vida (cuando sale de Egipto). En un segundo momento, Dios como madre muestra un cuidado especial por Israel en los comienzos de su vida: lo alimenta, lo protege, lo defiende y le da confianza y seguridad (imagen de la nube y columna de fuego que indican la presencia y guía constantes de Dios). Sin embargo, no lo sobreprotege e incluso lo castiga, lo va soltando poco a poco. Finalmente, Dios lo enseña a caminar en la libertad (etapa del desierto). Dios se representa como una madre comprensiva, misericordiosa y paciente...

4. En el Nuevo Testamento, sobresale la relación de Jesús con Dios, a quien le llama Abbá (Mt 23, 9; Mc 14, 36), un Dios próximo, cercano a sus hijos, que comparte sus sufrimientos; como una mezcla de padre/madre que añade un componente de ternura que no dominaba en el modelo familiar patriarcal del siglo I; en esta relación se hace presente la misericordia divina que se refleja en los textos del Antiguo Testamento.

En Mt 23, 37 se compara a Jesús con una gallina-madre que junta a sus crías: «iJerusalén, Jerusalén, la que mata a los profetas y apedrea a los que le son enviados! ¡Cuántas veces he querido reunir a tus hijos, como una gallina 
reúne a sus pollos bajo las alas, y no habéis querido!». Como una madre que protege y defiende a sus hijos.

Otros textos (Mc 1, 41) hablan de que Jesús se compadece, se le sacuden sus entrañas, las cuales son expresión de la capacidad de conmoverse, de no ser indiferente ante el dolor de los demás, de tener un corazón lleno de misericordia, capaz de ponerse en movimiento y ayudar a quien lo necesita. Esto lo demuestra Jesús en las parábolas sobre la misericordia (LC 15). El Dios de Jesús es el Dios de entrañas de madre, que no tiene nada que ver con el padre de la familia judía, lejano y autoritario. Jesús quedó configurado por la experiencia personal de un Dios padre-madre, lleno de ternura y misericordia: solidario con el sufrimiento ajeno, que sana y cura situaciones de dolor. Jesús llega a tener una misericordia que escandaliza a la rígida mentalidad religiosa y social de su tiempo.

Sólo a través de una imagen masculina y femenina de Dios que integre la plenitud de la humanidad se puede conseguir una mejor descripción y representación de lo divino. Por otra parte, hay que tomar en cuenta que Dios es una realidad siempre distinta de las construcciones humanas. A partir de las experiencias de Dios de las mujeres y de los hombres se puede hablar de Dios de un modo inclusivo, teniendo en cuenta que Dios está por encima de las divisiones de género. 